\title{
Phylogenetic Relationships of Termitomyces aurantiacus Inferred from Internal Transcribed Spacers DNA Sequences
}

\author{
Shafiquzzaman Siddiquee ${ }^{1}$, Kobun Rovina1 ${ }^{1}$, Laila Naher ${ }^{2}$, Kenneth F. Rodrigues ${ }^{1}$, \\ Md Akhter Uzzaman ${ }^{3}$ \\ ${ }^{1}$ Biotechnology Research Institute, Universiti Malaysia Sabah, Kota Kinabalu, Malaysia \\ ${ }^{2}$ Faculty of Agro-Based Industry, Universiti Malaysia Kelantan, Jeli Campus-17600, Kelantan, Malaysia \\ ${ }^{3}$ Planning and Development Division, Bangladesh Atomic Energy Commission, Dhaka, Bangladesh \\ Email: shafiqpab@ums.edu.my, ${ }^{*}$ shafiq.siddiquee@gmail.com
}

Received 10 April 2015; accepted 17 May 2015; published 20 May 2015

Copyright (C) 2015 by authors and Scientific Research Publishing Inc.

This work is licensed under the Creative Commons Attribution International License (CC BY). http://creativecommons.org/licenses/by/4.0/

(c) (i) Open Access

\begin{abstract}
Fungus-growing termites cultivate species of the mutualistic basidiomycete genus Termitomyces on a substrate called the fungal comb. Identification of fungal species based on morphological features is complicated, tedious, and prone to errors. As an alternative, nuclear ribosomal DNA sequences consisting of the internal transcribed spacers (ITS1 and ITS2) and 5.8S rDNA were used to identify Malaysian isolates of Termitomyces sp. The morphological characteristics and molecular data indicate that Malaysian Termitomyces isolated is clearly monophyletic and belongs to the Tricholomataceae family. The Malaysian isolates analyzed in this study represent the termite fungus species called T. aurantiacus.
\end{abstract}

Keywords

Fungal Comb, Internal Transcribed Spacers, Morphological Feature, Phylogenetic Relationship

\section{Introduction}

Fungus-growing termites (Macrotermitinae) are important keystone species in the Asian and African tropics, where they have a great impact on the decomposition of dead plant material [1] [2]. These termites cultivate species of the mutualistic basidiomycete genus Termitomyces. The fungi, which grow in association with termites and their nests, rely on the organic substances obtained by the insects when they feed on dead plant ma-

*Corresponding author.

How to cite this paper: Siddiquee, S., Rovina, K., Naher, L., Rodrigues, K.F. and Uzzaman, M.A. (2015) Phylogenetic Relationships of Termitomyces aurantiacus Inferred from Internal Transcribed Spacers DNA Sequences. Advances in Bioscience and Biotechnology, 6, 358-367. http://dx.doi.org/10.4236/abb.2015.65035 
terial [3]. Grasse' [4] first described Termitomyces as being associated with a single family of termites. Now over 330 species of fungus-growing termites in 11 genera are known [5], and 30 species of Termitomyces have been described [6]. Of these, 12 species of Termitomyces have been found in Southeast Asia [7]. Elucidating the taxonomy of these fungi is a difficult process [8], and it is likely that more species exist but have yet to be discovered.

The ectosymbiosis between termites and Termitomyces greatly affects the physical and chemical properties of the soil and its related microbial communities. Termitomyces is cultivated on a special substrate inside the termite nest or dispersed in the soil called the fungal comb or fungal garden [9]-[11]. Like fungus-growing ants and beetles, fungus-growing termites develop an "agricultural" mutualism by growing fungi for food [11]. The fungal combs are built with partially digested vegetal material and managed by termites to support the growth of Termitomyces and to prevent the combs' colonization by competitive fungi.

Classification of Termitomyces species based on morphological and physiological characteristics is very difficult [12]. Often, the morphological characteristics do not distinguish different species of fungus [13]. Moreover, sexual characteristics generally are not useful for classification because approximately $20 \%$ of fungal species are considered to be asexual, and those that can reproduce sexually do not do so regularly [14]. Some Termitomyces species also mainly reproduce asexually and those fruiting bodies are rarely seen for some species [15]. The inoculation of the fungus comb in newly founded of some species colonies of the Macrotermitinae (Isoptera) from Nigeria [16] [17]. Therefore, molecular techniques are required to provide quantitative data to understand the specificity of the association between particular fungus species and termites.

Ribosomal DNA (rDNA) sequences can be used for taxonomic and phylogenetic analyses to study relationships among species. The internal transcribed spacer (ITS) is a component of the rDNA repeat, which consists of 18S, ITS1, 5.8S, ITS2, and 28S genes. Ribosomal genes and spacers always occur in tandem repeats that are thousands of copies long, each separated by what is termed an intergenic spacer (IGS) or non-transcribed spacer (NTS). Each repeat is composed of a transcription unit that codes for three rRNAs: a small subunit (SSU), a large subunit (LSU), and 5.8S. ITS1 is a noncoding region located in rDNA between the 18S and 5.8S rRNA genes, whereas ITS2 is located between the 5.8S and 28S rRNA genes [18] [19]. Among the regions of the ribosomal cistron, the ITS regions have the highest probability of successful identification for the broadest range of fungi, with the most clearly defined barcode gap between inter- and intra-specific variation [20]. ITS2 is more useful for molecular systematics at the species level. Variation among individual rDNA repeats can be observed within both the ITS and IGS regions [17]. As the ITS sequences show more divergence than their flanking coding regions (5.8S rDNA, and also $18 \mathrm{~S}$ and $28 \mathrm{~S}$ ) and are easily amplified, they are routinely used to distinguish related species and to infer phylogenetic relationships among populations [21]. The aim of the present study was to confirm the identity of a Termitomyces species from Malaysia resembling T. aurantiacus.

\section{Materials and Methods}

\subsection{Sample Collection}

Four different fruiting body of termite were collected from an oil palm plantation located in the Seriserdang area during the months of July and August, 2008 (Table 1). The outermost layer of each fungus comb was peeled off and cut into $3 \mathrm{~mm}$ long segments. The segments were surface-sterilized in $70 \%$ ethanol followed by $0.05 \%$ sodium hypochlorite (or $5 \%$ Clorox $^{\circledR}$ bleaching agent) for 1 - 2 min, rinsed with sterile distilled water, and blotted dry on sterilized Whatmann no. 17 filter papers. All segments were placed on a potato dextrose agar (PDA) (Difco; USA) plate and incubated for 6 days under ambient laboratory conditions $\left(28^{\circ} \mathrm{C} \pm 2^{\circ} \mathrm{C}, 12 \mathrm{~h}\right.$ light and 12 $\mathrm{h}$ darkness). All subculturing of these isolates was performed using PDA that was prepared by adding $500 \mathrm{ml}$ of distilled water sterilized at $121^{\circ} \mathrm{C}$ for $15 \mathrm{~min}$ to $19 \mathrm{~g}$ of PDA. After the incubation period, fungus colonies could be seen as small whitish spots. Stock cultures were stored on agar slopes in $20 \mathrm{ml}$ universal bottles maintained at $10^{\circ} \mathrm{C}-15^{\circ} \mathrm{C}$ until used for further analysis.

\subsection{Liquid Culture of Isolates}

Fungus isolates from each of the four termite mounds were cultured in potato dextrose broth (PDB) (Difco) that was prepared according to the manufacturer's specifications [10]. Aliquots of $100 \mathrm{ml}$ of medium were decanted 
Table 1. Isolates of Termitomyces aurantiacus analyzed in this study.

\begin{tabular}{cccccc}
\hline Isolates No. & T. aurantiacus & Isolates code & Sampling date & Host genotype & Location \\
\hline 1 & T. aurantiacus & TA008 & 17 July, 2008 & Oil palm 2A & Stadium area, Seriserdang \\
2 & T. aurantiacus & TA004 & 22 July, 2008 & Oil palm 5B & Stadium area, Seriserdang \\
3 & T. aurantiacus & TA010 & 14 August, 2008 & Oil palm 8D & MTDC, Seriserdang \\
4 & T. aurantiacus & TA012 & 21 August, 2008 & Oil palm 7E & MTDC, Seriserdang \\
\hline
\end{tabular}

into individual $250 \mathrm{ml}$ Erlenmeyer flasks with cotton wool stoppers placed over the flask mouths and then autoclaved at $121^{\circ} \mathrm{C}$ for $15 \mathrm{~min}$. When cooled, each flask was aseptically inoculated with five agar disc pure cultures of fungi cut from actively growing hyphal tips using a $5 \mathrm{~mm}$ diameter cork borer. Once inoculated, the cotton wool stoppers were replaced with aluminum foil and the flasks were sealed with parafilm during the growth phase as static cultures under room temperature conditions $\left(28^{\circ} \mathrm{C} \pm 2^{\circ} \mathrm{C} ; 12 \mathrm{~h}\right.$ darkness and $\left.12 \mathrm{~h} \mathrm{light}\right)$. The flasks were maintained as still cultures for 10 days under ambient laboratory conditions. The mycelia mats were harvested by filtration through a double-layered muslin cloth and washed several times with sterile distilled water. The mycelia mats from each of the isolates were then transferred into individual plastic bags (with excess liquid squeezed out), labeled, and deep frozen overnight at $-20^{\circ} \mathrm{C}$. The frozen mycelia mats were immediately ground in a mortar and pestle swabbed with ethanol prior to use. The slurry obtained was stored at $-20^{\circ} \mathrm{C}$ or used immediately for DNA extraction.

\subsection{DNA Extraction}

The total fungal DNA was extracted using the phenol-chloroform method, as described in White et al. [22]. Approximately $50 \mathrm{mg}$ of ground mycelium were added to $500 \mu \mathrm{l}$ of extraction buffer (1 M Tris $\mathrm{HCl}[\mathrm{pH} \mathrm{8.5],} 1 \mathrm{M}$ $\mathrm{NaCl}$ [pH 8.5], $1 \mathrm{M}$ EDTA [pH 8.0] and 10\% sodium dodecyl sulphate). The reaction tubes were placed in a water bath for $8 \mathrm{~h}$ at $38^{\circ} \mathrm{C}$. After incubation, $350 \mu \mathrm{l}$ of buffered phenol and $150 \mu \mathrm{l}$ of chloroform were added and homogenously mixed for $10 \mathrm{~min}$. The resulting suspension was centrifuged at $13,000 \times g$ at $4{ }^{\circ} \mathrm{C}$ for $10 \mathrm{~min}$. The upper aqueous layer was collected and transferred to a sterile centrifuge tube to which $3 \mu 1$ of RNAse solution were added. This mixture was incubated at $38^{\circ} \mathrm{C}$ in a water bath for $15 \mathrm{~min}$. After incubation, an equal volume of chloroform was gently added to the sample and mixed for $10 \mathrm{~min}$. The mixture was then centrifuged once more $\left(13,000 \times g\right.$ for $10 \mathrm{~min}$ at $\left.4^{\circ} \mathrm{C}\right)$. The upper aqueous phase was again collected and transferred to a new tube. The DNA was precipitated with $250 \mu \mathrm{l}$ of iso-propan-2-ol and kept overnight at $-20^{\circ} \mathrm{C}$. The next day the tube was centrifuged at $13,000 \times g$ for $10 \mathrm{~min}$ at $4^{\circ} \mathrm{C}$. The resultant pellets were thoroughly washed twice with $500 \mu 1$ of $70 \%$ ethanol, vacuum dried, and diluted in $\mathrm{ddH}_{2} \mathrm{O}$. Finally, the DNA pellets were suspended in $50 \mu \mathrm{l}$ of $\mathrm{ddH}_{2} \mathrm{O}$ and kept at $-20^{\circ} \mathrm{C}$. Next, the quality of the DNA samples was checked by performing gel electrophoresis on $1.5 \%$ agarose gel using a $50 \mathrm{bp}$ (Promega, USA) ladder as a size standard. The electrophoresis was carried out in a $1 \times \mathrm{TBE}(0.045 \mathrm{M}$ Tris-borate and $1 \mathrm{mM}$ EDTA [pH 8.2]) running buffer at $70 \mathrm{~V}$ for $1-2 \mathrm{~h}$. The gels were then stained with ethidium bromide $(0.5 \mu \mathrm{l} / \mathrm{ml})$ and visualized under UV light. The appearance of bands indicated the presence of a DNA template, which thereby allowed their use for polymerase chain reaction (PCR).

\subsection{PCR Amplification of the ITS Regions of the rDNA}

The universal forward primer ITS1 (5' TCC GTA GGT GAA CCT GCG G 3') and the reverse primer ITS4 (5' TCC TCC GCT TAT TGA TAT GC 3') were used for the amplification of the ITS1 and ITS2 regions of the rDNA [23]. The PCR amplifications were performed in a total reaction volume of $50 \mu$ consisting of $50 \mathrm{ng}$ genomic DNA, $10 \mathrm{mM}$ dNTPs, $100 \mathrm{mM} \mathrm{MgCl}$, 5,000 units/ml of Taq DNA polymerase placed in a reaction buffer concentration of $10 \times$ PCR buffer $(200 \mathrm{mM}$ Tris $\mathrm{HCl}, \mathrm{pH} 8.4$ and $500 \mathrm{mM} \mathrm{KCl})$, and $1 \mu \mathrm{M}$ primers of ITS1 and ITS4. The reactions were conducted in a Peltier Thermal Cycler-200 as follows: an initial denaturation for 5 min at $95^{\circ} \mathrm{C}$ followed by 36 cycles of $1 \mathrm{~min}$ at $94^{\circ} \mathrm{C}$, annealing at $55^{\circ} \mathrm{C}$ for $1 \mathrm{~min}$, extension at $72^{\circ} \mathrm{C}$ for $3 \mathrm{~min}$, and a final extension at $72^{\circ} \mathrm{C}$ for $10 \mathrm{~min}$. 


\subsection{Gel Electrophoresis}

The PCR products were run on a $1.5 \%$ agarose gel with a $100 \mathrm{bp}$ (Promega) ladder as the size standard. Electrophoresis was performed in $1 \times$ TBE running buffer $(0.045 \mathrm{M}$ Tris-borate and $1 \mathrm{mM}$ EDTA, pH 8.2) at $70 \mathrm{~V}$ for $1-2 \mathrm{~h}$. The gels were then stained with ethidium bromide $(0.5 \mu \mathrm{l} / \mathrm{ml})$. After $15-30 \mathrm{~min}$ the gels were visualized under UV light and photographed using an Alphamager ${ }^{\circledR} 2200$ version 5.5 gel documentation systems.

\subsection{DNA Sequencing and Alignment}

The PCR products $(50 \mu \mathrm{l})$ were purified using a commercial kit (QIAquick ${ }^{\circledR}$ PCR Purification Kit, Canada). The purified PCR products were sequenced using the BigDye Terminator v3.1 kit on an AB13130 DNA Sequencer (Applied Biosystems, USA). All of the sequence data were subjected to multiple alignments using the Bio-Edit Sequence Alignment Editor Software. Multiple sequence alignments were performed in NEXUS format using the default option in CLUSTAL-W software version 1.83 [24] in BioEdit Sequence Alignment Editor. The alignment was then optimized manually. Single gaps were treated as a fifth nucleotide (A, C, G, T, and gaps). Nucleotide sequences were subjected to GenBank searches to look for similar sequences. Isolate TA 004 sequences were submitted and deposited in a GenBank under accession number GU594650 for the ITS1 and ITS2 regions of the rDNA.

\subsection{Phylogenetic Tree Analysis}

Phylogenetic analyses were performed in MEGA6 software package [25]. The phylogenetic tree was reconstructed using the neighbor-joining (NJ) method of Saitou and Nei [26]. Bootstrap tests with 1,000 replications were conducted to examine the support of the interior branches and the validity of the phylogenetic analysis was obtained. Distance was defined as the probability of the nucleotide substitutions per site, based on the Kimura 2-parameter model (K2P) [27].

\section{Results}

\subsection{Morphology Observation}

The colony growth rate of T. aurantiacus was 10 - $15 \mathrm{~mm}$ per day on PDA at room temperature. The colony was initially watery-white but turned a grayish slightly light white color in the centre of the Petri dish after 4 days of culture. When the colony fully covered the whole plate, it was grayish in color. By days $7-8,50 \%-60 \%$ of the colony was dark gray and the remaining 40\% - 50\% was dull gray (Figure 1) looking at the bottom of the dish, the colony was red in color (Figure 1).

The diameter of the pileus of the isolates was $5-8 \mathrm{~cm}$. The pileus were convexo-mucronate with a pointed perforatorium, finally applanate with a recurved margin and the surface was rusty ochraceous to orange, the color was dark brown over the perforatorium, which was finely striated, somewhat scrobiculate towards the centre, and glabrous or with fine, and scattered velar remnants (Figure 2 and Figure 3, respectively). The stipe was a 6 - 8 $\times 0.7-1.0 \mathrm{~cm}$ long cylindrical solid with a white or whitish surface, and the annular zone was indistinct or absent. The pseudorhiza was $20-25 \mathrm{~cm}$ long and white in color.

\subsection{Phylogenetic Analysis}

The products of PCR amplification of the ITS 1-5.8S-ITS 2 regions of T. aurantiacus of TA008, TA004, TA010 and TA012 isolates were $\sim 500 \mathrm{bp}$ in length, as expected (Figure 4). Comparisons of the sequences were showed that the four fungus isolates from the fungus combs sampled from the four termite mounds were very similar. The DNA sequences of the ITS1-5.8S-ITS 2 regions of these four fungus isolates were showed more than $99 \%$ nucleotide identity to one another (Figure 5). Strains of TA008, TA004, TA010 and TA012 and ex-strains of GU594650 (Termitomyces aurantiacus strain TA 06; [28], JN585945 (T. aurantiacus strain Cs/10/2; [29]) JQ228252 (T. aurantiacus strain CB55; [30]) were showed approximately 99\% nucleotide identity to each other in Clade 1. Strains of 93073101 (EU179869; [31]), 95060509 (EU179866; [32]), XF1 (HQ435673; [33]), XF15 (HQ435671; [33]), 2735 (EU272539; [34]) and XF10 (Xylaria; HQ435666; [33]) were showed about 77\% nucleotide identity to each other in Clade 2. The grouping of the data (Clades 1 and 2) was supported to different the grouping in the cases. These results suggested that the four isolates were Termitomyces-related basidiomy 


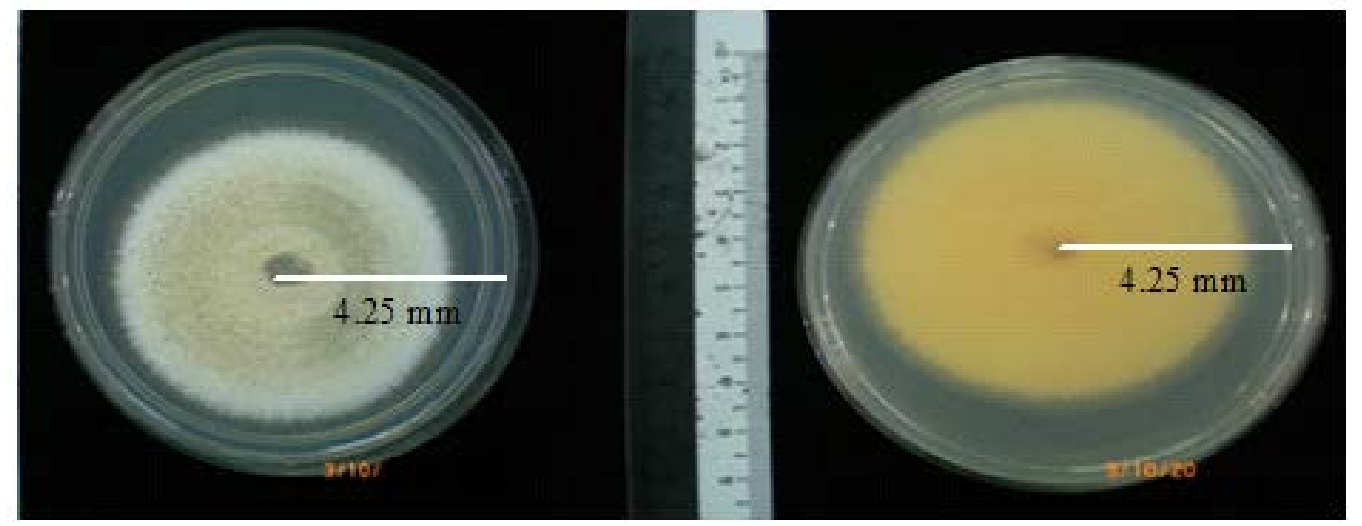

Figure 1. Seven days old colony of Termitomyces aurantiacus onto PDA media (left) and the reverse (right).

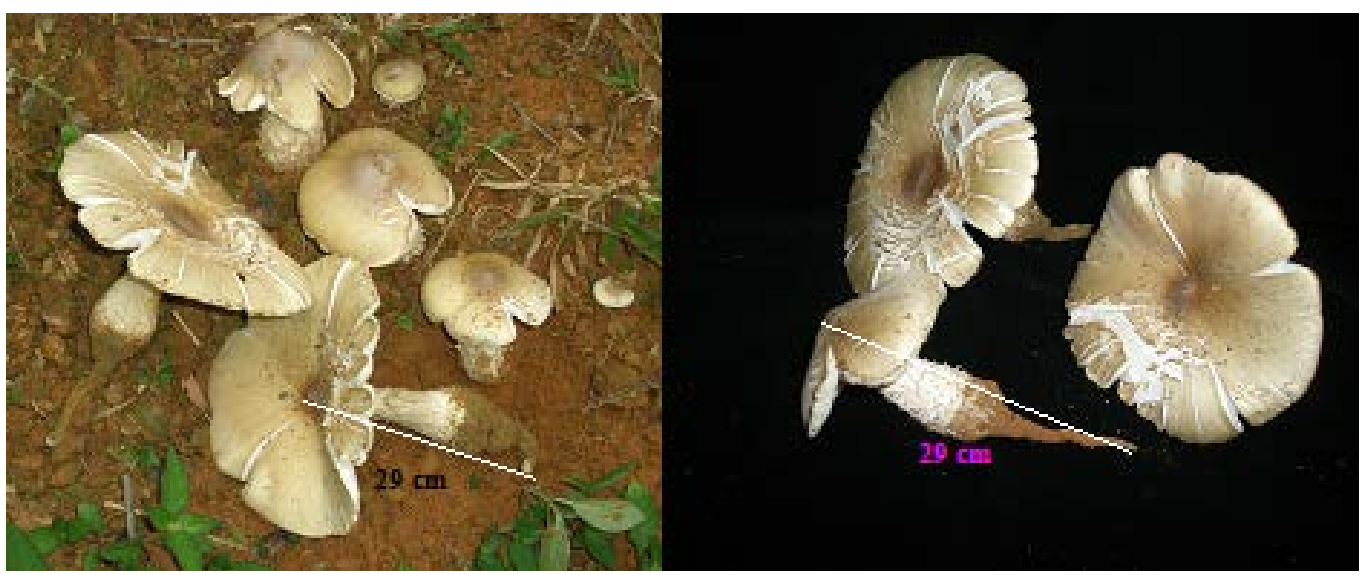

Figure 2. T. aurantiacus attached to termite nest (left) and after collection (right).

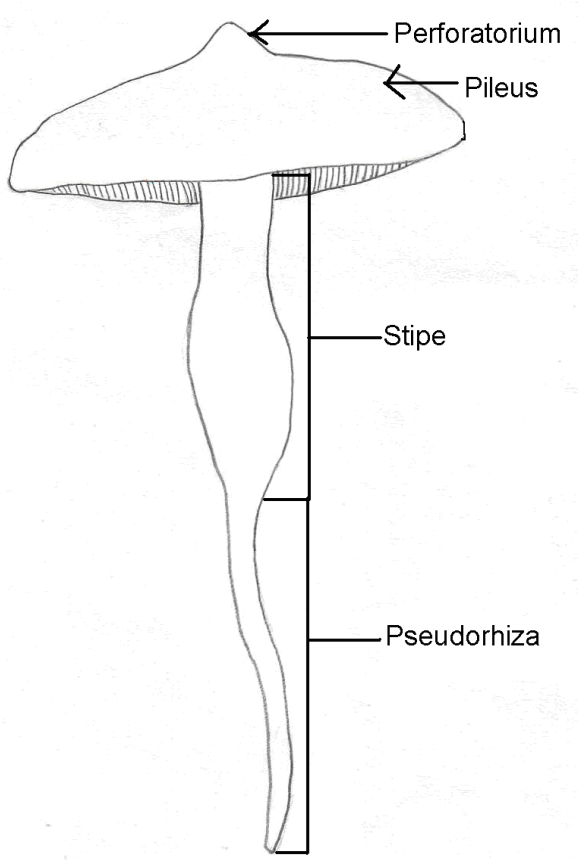

Figure 3. A schematic illustration of T. aurantiacus. 


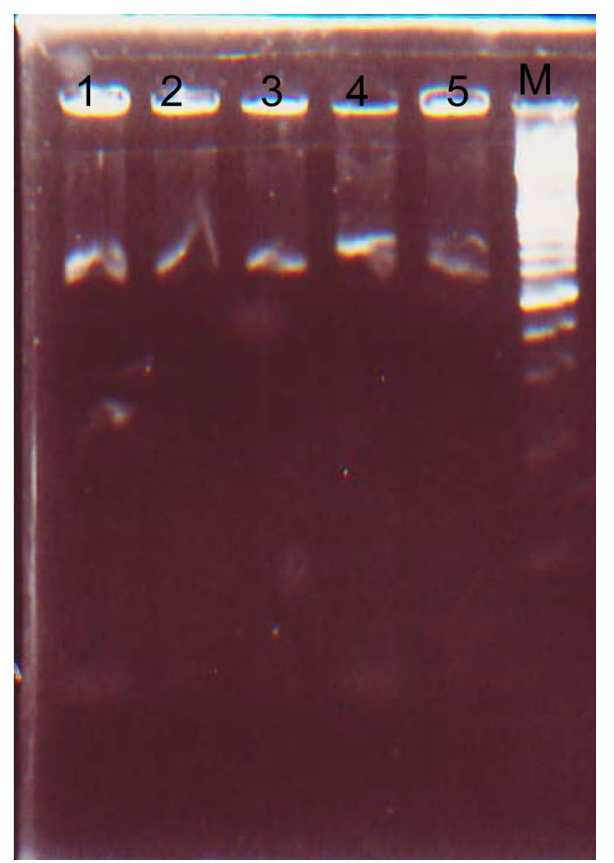

Figure 4. Banding patterns produced of $T$. aurantiacus isolates by using the primer ITS-1 and ITS-4.

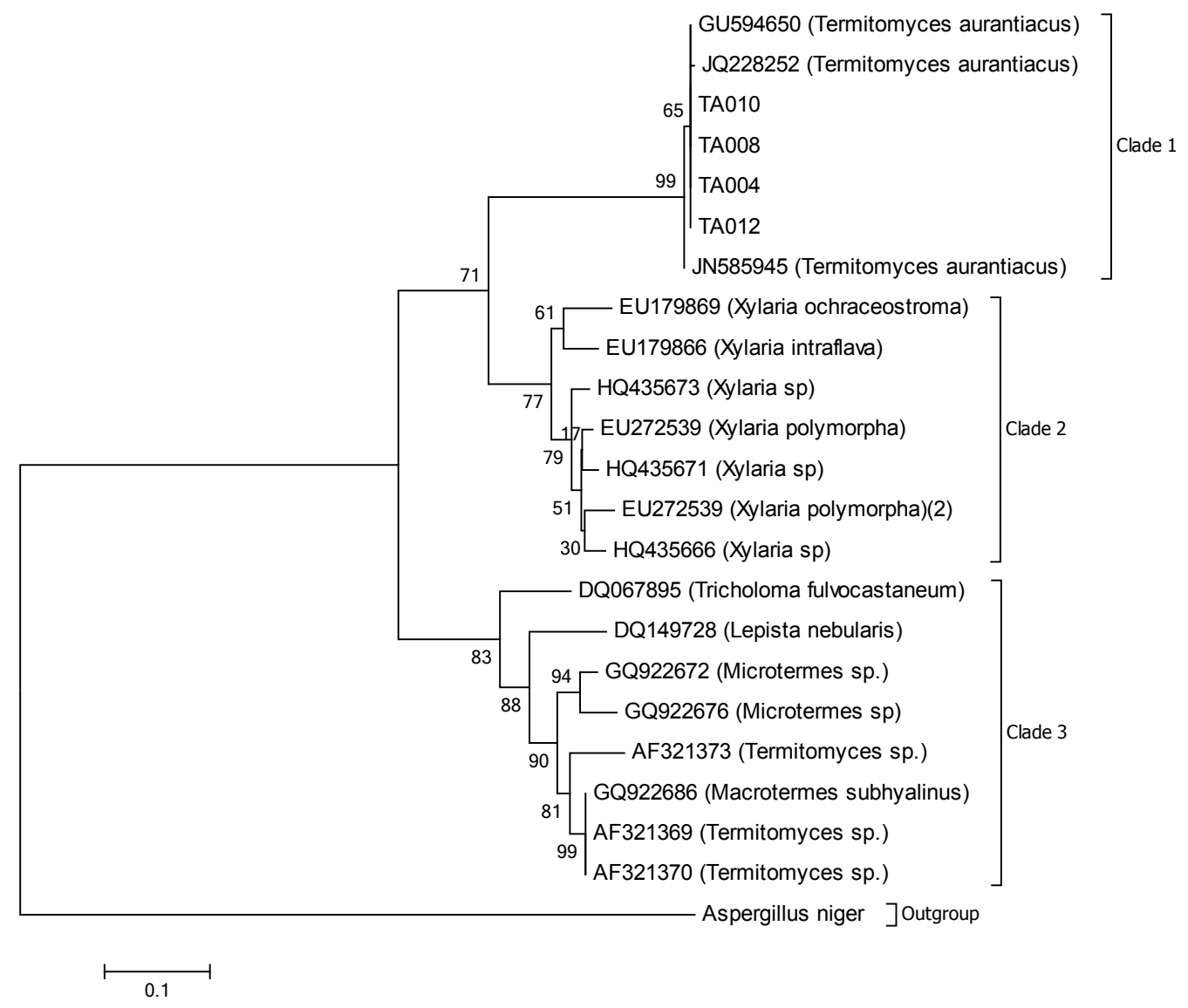

Figure 5. Phylogenetic tree (neighbor-joining (NJ) is showing relationship of isolates with other related fungal species retrieved from GenBank based on their sequence of the ITS 1-5.8S-ITS 2 regions of the rDNA. 
cetes and confirm that $T$. aurantiacus was the symbiont found growing on the fungus comb as fungus nodules. The phylogenetic tree analyses of the ITS1-5.8S-ITS2 regions found that all strains in clade 3 clustered with Tricholoma fulvocastaneum (T. fulvoca, DQ067895; [35]), Lepista nebularis (Lnebular, DQ149728; [36]), Termitomyces associated with Macrotermes subhylainus (GQ922686; [37]), Termitomyces sp. (AF321369, AF321370 and AF321373; [11]), and Termitomyces associated with Microtermes sp. (GQ922672 and GQ922676; [37]) shown in Figure 4. This clustering was fully supported by the statistical analyses and showed $83 \%$ bootstrap values for the NJ method.

\section{Discussion}

Termites of the subfamily Macrotermitinae live in a mutualistic symbiosis with basidiomycete fungi of the genus Termitomyces. Termitomyces is commonly found in equatorial and southern Africa and in Southeast Asia. These genera are edible mushrooms, widely collected and traded in many countries of Southeast Asia [7]. It is closely related to Termitomyces striatus (Beeli) Heim, and is described from equatorial Africa as a variety of that species. Termitomyces aurantiacus is a familiar edible species in Thailand. In Africa, the symbotic association is with the termite, Pseudacanthotermes militaris Hagen [7]. Termites of subfamily Macrotermitinae cultivate the mycelium of basidiomycetes on comb-like structures made of small spheres of plant material quickly passed through the termite gut. The termites consumed small nodule that produced by the fungus, along with the degraded comb. This symbiotic association is quite similar to the protozoic endosymbionts of non-fungus growing termites [38]. Sometimes, frequently in correlation with rain seasons, the fungal mycelium of the termite combs produces mushrooms, which penetrate the termite nests and soil to spread their spores [8].

Grassé [4] reported that every genus of fungus-growing termites is associated with a single species of Termitomyces that probably encompasses different morphospecies. Fifty years ago, Sands [39] reported some degree of specificity between termite genera and the associated fungal species. Heim [8] later suggested a strict system of one host and one fungal species. However, this premise was contradicted by other studies based on morphological characterizations of fungi, which suggested that certain fungi were shared by different termite host species and even genera [2].

Classification of fungi based on the observation of various morphological features originally played a key role in providing putative species names, but accurate identification of species was very complicated, laborious, and subjective. Davet and Rouxel [40] noted that traditional identification methods could result in an overestimate of species, whereas those in the mycelial state or those with slow growth in culture were largely overlooked. In our opinion, the taxonomic classification of Termitomyces fungi still has limitations. Many species that appear to be similar under culture conditions and exhibit similar morphology are in fact completely different species. Processing of fungus cultures can be time consuming and laborious when a large number of isolates have to be handled, and the risk of culture contamination is always high, especially for the fast-growing fungi that overgrow the entire culture medium. As such, it is recommended that a multi-disciplinary approach be used for the accurate identification of Termitomyces species.

Molecular techniques allow the analysis of genetic markers and establish the identity of individuals as well as the taxonomic and phylogenetic relationships among individuals. The rDNA regions are commonly used for taxonomic and phylogenetic studies because they contain variable and conserved domains, which permit discrimination at the genus, species, and sub-species levels. The noncoding ITS1 and ITS2 regions in particular can be used for discrimination among closely related species within a fungal genus [12].

The ITS 1 and 2 regions of the rDNA of isolates (TA004, TA008, TA010 and TA012) were successfully amplified by PCR with expected length of $\sim 500 \mathrm{bp}$. Homology searching against GenBank revealed that these sequences were $100 \%$ similar with those of T. aurantiacus, and that none of the sequenced isolates belonged to the genus Xylaria. A phylogenetic relationship was established through alignment and cladistic analysis of homologous nucleotide sequences among these fungal species (Figure 5); the isolates were found to belong to the genus Termitomyces. According to this phylogenetic analysis, isolates were a species variant of T. aurantiacus.

The phylogenetic study showed the monophyletic tree from pure Malaysian Termitomyces isolates and mixture of Asia and African Termitomyces samples and suggested that both Asia and African Termitomyces species should have evolved from the same Clade 1 (Figure 5). The mutualistic symbiosis between fungus-growing termites and Termitomyces fungi originated in Africa and showed a moderate degree of interaction specificity. Approximately 30 species of Termitomyces from Africa and Asia have been described [6]. Osiemo et al. [41] 
combined available ITS sequence data from West, Central, and South Africa with data of 39 new samples from East Africa to achieve the most comprehensive view of the diversity and host specificity of Termitomyces symbionts across Africa. A high amount of sequence divergence in the ITS sequences is found; 11 different Termitomyces lineages in East Africa and $>30$ lineages across Africa are identified, and the expected diversity is estimated to be about 41 lineages.

Analysis of phylogenetic tree based on Xyleria ITS sequences are well-fitted in clade 2, with similarity boot strap value of $77 \%$. Rogers et al. [42] reported that Xylaria-like fungi inhabited the fungus comb as mycelia. However, they never produce spores or stroma until the fungus comb is removed from the nest or termite abandon the nest. When fungus comb from a healthy nest incubates in the absence of termites, it is often covered by vigorous mycelium of Xylaria within a few days [43] [44]. Sannasi [45] described X. nigripes as the cultivated symbiont of Odontotermes redemanni, without mentioning Termitomyces. Visser et al. [46] reported that the identical ITS types occurred on fungus combs from different termite genera and species.

The above conclusion is that based on morphology and phylogeny, the identity of the species is $T$. aurantiacus. In conclusion, the above discussion strongly suggested that the combined morphology and phylogeny characters are undoubtedly useful for accurately identifications at the species level as a paradigm reference for further identification of T. aurantiacus species.

\section{Acknowledgements}

The authors acknowledge the valuable contributions of the late Prof. Dr. Faridah Abdullah. This work was supported by the Ministry of Science, Technology and Innovation Malaysia (MOSTI) under vote No. 01-02-046020 EA001.

\section{References}

[1] Abe, T. and Matsumoto, T. (1979) Studies on the Distribution and Ecological Role of Termites in a Lowland Rainforest of West Malaysia. 3. Distribution and Abundance of Termites in Pasoh Forest Reserve. Japanese Journal of Ecology, 29, 337-351.

[2] Wood, T.G. and Sands, W.A. (1978) The Role of Termites in Ecosystems. In: Brain, M.V., Ed., Production Ecology of Ants and Termites. Cambridge, Cambridge University Press, 245-292.

[3] Schuurman, G. (2005) Decomposition Rates and Termite Assemblage Composition in Semiarid Africa. Ecology, 86, 1236-1249. http://dx.doi.org/10.1890/03-0570

[4] Grassé, P.P. (1959) Une nouveau type de symbiose: La meule alimentaire des termites champignonnistes. Nature, 3293, 385-389.

[5] Kambhampati, S. and Eggleton, P. (2000) Taxonomy and Phylogenetics of Isoptera. In: Abe, T., Bignell, D.A. and Higashi, M., Eds., Termites: Evolution, Sociality, Symbioses and Ecology, Kluwer Academic Publishers, Dordrecht, 1-23. http://dx.doi.org/10.1007/978-94-017-3223-9_1

[6] Kirk, P.M., Cannon, P.F., Minter, D.W., et al. (2008) Ainsworth \& Bisbys Dictionary of the Fungi. 10th Edition, CABI Publishing, Wallingford, 771.

[7] Pegler, D.N. and Vanhaecke, M. (1994) Termitomyces of Southeast Asia. Kew Bulletin, 49, 717-736. http://dx.doi.org/10.2307/4118066

[8] Heim, R. (1977) Termites et Champignons. Les champignons termitophiles d'Afrique Noire et d'Asie me'ridionale. E' ditions Boube'e, Paris, 205 p.

[9] Aanen, D.K., Eggleton, P., Rouland-Lefevre, C., et al. (2002) The Evolution of Fungus-Growing Termites and Their Mutualistic Fungal Symbionts. Proceedings of the National Academy of Sciences of the United States of America, 99, 14887-14892. http://dx.doi.org/10.1073/pnas.222313099

[10] Froslev, T.G., Aanen, D.K., Laessoe, T. and Rosendahl, S. (2003) Phylogenetic Relationships of Termitomyces and Related Taxa. Mycological Research, 107, 1277-1286. http://dx.doi.org/10.1017/S0953756203008670

[11] Rouland-Lefevre, C. (2000) Symbiosis with Fungi. In: Abe, T., Bignell, D.E. and Higashi, M., Eds., Termites: Evolution, Sociality, Symbioses, Ecology, Kluwer Academic Publishers, Dordrecht, 289-306. http://dx.doi.org/10.1007/978-94-017-3223-9_14

[12] Edel, V. (1998) Use of PCR and RFLP in Fungal Systematic. In: Frisvad, J.C., Bridge, P.D. and Arora, D.K., Eds., Chemical Fungal Taxonomy, Marcel Dekka Inc., New York, 51-76.

[13] Taylor, J.W., Jacobson, D.J., Kroken, S., Kasuga, T., Geiser, D.M., Hibbett, D.S. and Fisher, M.C. (2000) Phylogenetic Species Recognition and Species Concepts in Fungi. Fungal Genetics and Biology, 31, 21-32. 
http://dx.doi.org/10.1006/fgbi.2000.1228

[14] Reynolds, J., Weir, B.S. and Cockerham, C.C. (1983) Estimation of the Coancestry Coefficient: Basis for a Short-Term Genetic Distance. Genetics, 105, 767-779.

[15] Johnson, R.A., Thomas, R.J., Wood, T.G. and Swift, M.J. (1981) The Inoculation of the Fungus Comb in Newly Founded Colonies of Some Species of the Macrotermitinae (Isoptera) from Nigeria. Journal of Natural History, 15, 751-756. http://dx.doi.org/10.1080/00222938100770541

[16] De Fine Licht, H.H., Boomsma, J.J. and Aanen, D.K. (2006) Presumptive Horizontal Symbiont Transmission in the Fungus-Growing Termite Macrotermes natalensis. Molecular Ecology, 15, 3131-3138. http://dx.doi.org/10.1111/j.1365-294X.2006.03008.x

[17] Nobre, T., Fernandes, C., Boomsma, J.J., Korb, J. and Aanen, D.K. (2011) Farming Termites Determine the Genetic Population Structure of Termitomyces Fungal Symbionts. Molecular Ecology, 20, 2023-2033. http://dx.doi.org/10.1111/j.1365-294X.2011.05064.x

[18] Hagn, A., Wallisch, S., Rad, V., Munch, J.C. and Schloter, M. (2007) A New Cultivation Independent Approach to Detect and Monitor Common Trichoderma Species in Soils. Journal of Microbiological Methods, 69, 86-92. http://dx.doi.org/10.1016/j.mimet.2006.12.004

[19] Jansen, G., Devaere, S., Weekers, P.H.H. and Adriaens, D. (2006) Phylogenetic Relationships and Divergence Time Estimate of African Angulliform Catfish (Siluriformes: Clariidae) Inferred from Ribosomal Gene and Spacer Sequences. Molecular Phylogenetics and Evolution, 38, 65-78. http://dx.doi.org/10.1016/j.ympev.2005.09.011

[20] Schocha, C.L., Seifertb, K.A., Huhndorf, S., Robertd, V., Spougea, J.L., André Levesqueb, C., et al. (2012) Fungal Barcoding Consortiuma, Nuclear Ribosomal Internal Transcribed Spacer (ITS) Region as a Universal DNA Barcode Marker for Fungi. PNAS, 109, 6241-6246.

[21] Young, I. and Coleman, A.W. (2004) The Advantages of the ITS2 Region of the Nuclear rDNA Cistron for Analysis of Phylogenetic Relationships of Insects: A Drosophila Example. Molecular Phylogenetics and Evolution, 30, $236-242$. http://dx.doi.org/10.1016/S1055-7903(03)00178-7

[22] White, T.J., Bruns, T., Lee, S. and Taylor, J.W. (1990) Amplification and Direct Sequencing of Fungal Ribosomal RNA Genes for Phylogenetics. In: Innis, M.A., Gelfand, D.H., Sninsky, J.J. and White, T., Eds., PCR Protocols, Academic Press, San Diego, 315-322.

[23] Siddiquee, S., Yee, W.Y., Taslima, K., Fatihah, N.H.N., Kumar, S.V. and Hasan, M.M. (2012) Sequence Analysis of the Ribosomal DNA Internal Transcribed Spacer Regions in Termitomyces heimii Species. Annals of Microbiology, 62, 797-803. http://dx.doi.org/10.1007/s13213-011-0320-8

[24] Thompson, J., Higgins, D. and Gibson, T. (1994) Clustal W: Improving the Sensitivity of Progressive Multiple Sequence Alignment through Sequence Weighting Position-Specific Gap Penalties and Weight Matrix Choice. Nucleic Acids Research, 22, 4673-4680. http://dx.doi.org/10.1093/nar/22.22.4673

[25] Tamura, K., Stecher, G., Peterson, D., et al. (2013) MEGA6: Molecular Evolutionary Genetics Analysis Version 6.0. The Society for Molecular Biology and Evolution, Oxford University, Oxford.

[26] Saitou, N. and Nei, M. (1987) The Neighbour-Joining Method: A New Method for Reconstructing Phylogenetic Trees. Molecular Phylogenetics and Evolution, 4, 406-425.

[27] Kimura, M. (1980) A Simple Method for Estimating Evolutionary Rates of Base Substitutions through Comparative Studies of Nucleotide Sequences. Applied and Environmental Microbiology, 16, 111-120. http://dx.doi.org/10.1007/bf01731581

[28] Siddiquee, S., Esmarada, A.K.W. and Abdullah, F. (2010) The Taxonomic Identity of Termitomyces aurantiacus by Using the Internal Transcribed Spacers 1 and 2 Regions of the rDNA. Mycology and Plant Pathology Lab, Department of Biology, University Putra Malaysia, UPM Serdang.

[29] You, Y.H., Yoon, H., Kang, S.M., et al. (2013) Cadophora malorum Cs-8-1 as a New Fungal Strain Producing Gibberellins Isolated from Calystegia soldanella. Journal of Basic Microbiology, 53, 630-634. http://dx.doi.org/10.1002/jobm.201200002

[30] He, Y., Tian, Y., Ye, R. and Ma, L. (2011) Isolation, Characterization and Antimicrobial Activity of Endophytic Fungi from Polygonum cuspidatum Sieb. et Zucc. School of Chemical Engineering, Sichuan University, Chengdu.

[31] Ju, Y.M. and Hsieh, H.M. (2007) Xylaria Species Associated with Nests of Oontotermes formosanus in Taiwan. Mycology, 99, 936-957. http://dx.doi.org/10.3852/mycologia.99.6.936

[32] Hsieh, H.M., Lin, C.R., Fang, M.J., Rogers, J.D., Fournier, J., Lechat, C. and Ju, Y.-M. (2010) Phylogenetic Status of Xylaria subgenus Pseudoxylaria among Taxa of the Subfamily Xylarioideae (Xylariaceae) and Phylogeny of the Taxa Involved in the Subfamily. Molecular Phylogenetics and Evolution, 54, 957-969.

http://dx.doi.org/10.1016/j.ympev.2009.12.015 
[33] Reddy, S.M., Suryanarayanan, T.S., Aggarwal, A. and Babu, G.A. (2010) Endophytic Xylariaceae of Western Ghats, Southern India: Diversity and Bioactive Compounds. Department of Biotechnology, Thapar University, Patiala.

[34] Restrepo, S., Avila, L., Lopera, C., et al. (2007) Fungal Endophytes from an Andean Colombian Paramo Ecosystem Inhibit the in Vitro Growth of Plant Pathogens. Biological Sciences, Los Andes University, Bogota.

[35] Sanmee, R., Dell, B., Lumyong, P. and Lumyong, S. (2007) First Record of Tricholoma fulvocastaneum from Thailand. Mycoscience, 48, 131-133. http://dx.doi.org/10.1007/S10267-006-0341-5

[36] Sabotic, J., Gaser, D., Rogelj, B., Gruden, K., Štrukelj, B. and Brzin, J. (2006) Heterogeneity in the Cysteine Protease Inhibitor Clitocypin Gene Family. Biological Chemistry, 387, 1559-1566. http://dx.doi.org/10.1515/BC.2006.194

[37] Nobre, T., Eggleton, P. and Aanen, D.K. (2010) Vertical Transmission as the Key to the Colonization of Madagascar by Fungus-Growing Termites? Proceedings of the Royal Society B: Biological Sciences, 277, 359-365. http://dx.doi.org/10.1006/mpev.2001.1071

[38] Rouland-Lefevre, C., Diouf, M.N., Brauman, A. and Neyra, M. (2002) Phylogenetic Relationships in Termitomyces (Family Agaricaceae) Based on the Nucleoticle Sequence of ITS: A First Approach to Elucidate the Evolutionary History of the Symbiosis between Fungus-Growing Termites and Their Fungi. Molecular Phylogenetics and Evolution, 22, 423-429.

[39] Sands, W.A. (1969) The Association of Termites and Fungi. In: Krishna, K. and Weesner, F.M., Eds., Biology of Termites, Academic Press, London, 495-524. http://dx.doi.org/10.1016/b978-0-12-395529-6.50020-9

[40] Davet, P. and Rouxel, F. (1997) Détection et isolement des champignons du sol. INRA, Paris, 203 p.

[41] Osiemo, Z.B., Marten, A., Kaib, M., Gitonga, L.M., Boga, H.I. and Brandl, R. (2010) Open Relationships in the Castles of Clay: High Diversity and Low Host Specificity of Termitomyces Fungi Associated with Fungus-Growing Termites in Africa. Insectes Sociaux, 57, 351-363. http://dx.doi.org/10.1007/s00040-010-0092-3

[42] Rogers, J.D., Ju, Y.M. and Lehmann, J. (2005) Some Xylaria Species on Termite Nests. Mycologiga, 97, $914-923$. http://dx.doi.org/10.3852/mycologia.97.4.914

[43] Shinzato, N., Muramatsu, M., Watanabe, Y. and Matsui, T. (2005) Termite-Regulated Fungal Monoculture in Fungus Combs of a Macrotermitine Termite Odontotermes formosanus. Zoological Science, 22, 917-922. http://dx.doi.org/10.2108/zsj.22.917

[44] Okane, I. and Nakagiri, A. (2007) Taxonomy of an Anamorphic Xylariaceous Fungus from a Termite Nest Found Together with Xylaria angulosa. Mycoscience, 48, 240-249. http://dx.doi.org/10.1007/S10267-007-0361-9

[45] Sannasi, A. (1969) Possible Factor Responsible for Specific Growth of Xylaria nigripes in the Fungus Garden of the Mounds of the Termite Odontotermes redemanni. Entomologia experimentalis et applicata, 12, 183-190. http://dx.doi.org/10.1111/j.1570-7458.1969.tb02513.x

[46] Visser, A.A., Ros, V.I., De Beer, Z.W., Debets, A.J.M., Hartog, E., Kuyper, T.W., et al. (2009) Levels of Specificity of Xylaria Species Associated with Fungus-Growing Termites: A Phylogenetic Approach. Molecular Ecology, 18, 553567. http://dx.doi.org/10.1111/j.1365-294X.2008.04036.x 